\title{
PENGARUH KEPEMILIKAN MANAJERIAL, KEPEMILIKAN INSTITUSIONAL, KEBIJAKAN DIVIDEN DAN INVESTMENT OPPORTUNITY SET TERHADAP NILAI PERUSAHAAN PADA PERUSAHAAN MANUFAKTUR YANG TERDAFTAR DI BURSA EFEK INDONESIA (BEI) TAHUN 2016-2018
}

\author{
Ni Nyoman Yuningsih ${ }^{1}$ \\ Ni Luh Gde Novitasari²
}

\author{
Fakultas Ekonomi dan Bisnis Universitas Mahasaraswati Denpasar ${ }^{1,2}$ \\ email: luhgdenovitasari@yahoo.com
}

\begin{abstract}
Financial performance can be used as a benchmark in assessing a company's financial success. Financial performance is a measure that describes the financial condition and ability of companies to make a profit. This study aims to reexamine the effect of environmental performance, corporate social responsibility, and good corporate governance on corporate financial performance. The sample in this study were 55 mining companies listed on the Indonesia Stock Exchange for the period 2014 - 2018. Determination of the sample using a purposive sampling method. The analytical tool used is multiple linear regression analysis. The results showed that environmental performance had no effect on financial performance and corporate social responsibility had a negative effect on financial performance. However, good corporate governance has a positive effect on financial performance.
\end{abstract}

Keywords: financial performance, environmental performance, corporate social responsibility, good corporate governance.

\section{PENDAHULUAN}

Tujuan setiap perusahaan baik perusahaan go public maupun perusahaan bukan go public adalah meningkatkan nilai perusahaan. Jensen dan Meckling (1976) dalam proses memaksimalkan nilai perusahaan akan muncul konflik kepentingan antara manajer dan pemegang saham (pemilik perusahaan) yang sering disebut agency problem. Dalam kasus PT. Maxpower terlihat bahwa pihak manajerial dan institusional yang juga merupakan pemegang saham perusahaan tidak menjalankan perannya dengan baik sehingga menimbulkan konflik dengan pemegang saham yang lain dan berdampak pada pihak lainnya.
Kepemilikan manajer dalam perusahaan akan dapat mengurangi masalah agensi, menurunkan biaya agensi (agency cost), mengurangi asimestris informasi, dan meminimalkan tindakan manipulasi data keuangan oleh manajer. Menurut penelitian Ningsih (2013) yang mengemukakan bahwa kepemilikan manajerial berpengaruh positif pada nilai perusahaan. Kepemilikan institusional, yang diartikan sebagai kepemilikan saham perusahaan oleh institusi atau lembaga tertentu (Tarjo, 2008). Kepemilikan institusional juga dapat dijadikan pengawasan dalam pengambilan keputusan oleh manajer. Hal ini dikarenakan kepemilikan institusional tidak mudah 
percaya terhadap kecurangan atau memanipulasi laba pada laporan keuangan. Dalam meningkatkan nilai perusahaan kebijakan dividien dan investment opportunity set juga berpengaruh dimana kebijakan dividen Kebijakan dividen menyangkut keputusan yang akan dibayarkan sebagai dividen atau ditahan untuk reinvestasi dalam perusahaan. Investor merasa lebih aman untuk memperoleh pendapat berupa pembayaran dividen yang lebih pasti dari pada menunggu capital gains yang lebih berisiko. Sehingga dividen yang tinggi akan meningkatkan nilai perusahaan. Menurut temuan Sasurya dan Asandrimitra (2013) menyebutkan bahwa kebijakan dividen berpengaruh positif terhadap nilai perusahaan. Investment opportunity set juga merupakan faktor yang mempengaruhi nilai perusahaan, investment opportunity set yang merupakan pilihan kesempatan investasi masa depan yang dapat mempengaruhi pertumbuhan aktiva perusahaan atau proyek yang memiliki net present value positif. Kallapur dan Trombley (2001) menyatakan bahwa kesempatan investasi perusahaan merupakan komponen penting dari nilai pasar dan berpengaruh positif terhadap nilai perusahaan. Berdasarkan latar belakang di atas, maka peneliti ingin melakukan penelitian dengan judul "Pengaruh Kepemilikan Manajerial, Kepemilikan Institusional, Kebijakan Dividen dan Investment Opportunity Set terhadap Nilai Perusahaan".

\section{Rumusan Masalah}

Berdasarkan pemaparan latar belakang di atas, maka dapat dirumuskan pokok permasalahan sebagai berikut:
1. Apakah kepemilikan manajerial berpengaruh terhadap nilai perusahaan manufaktur yang terdaftar di Bursa Efek Indonesia Tahun 2016 - 2018?

2. Apakah kepemilikan institusional berpengaruh terhadap nilai perusahaan manufaktur yang terdaftar di Bursa Efek Indonesia Tahun 2016 - 2018?

3. Apakah kebijakan dividen berpengaruh terhadap nilai perusahaan manufaktur yang terdaftar di Bursa Efek Indonesia Tahun 2016 - 2018?

4. Apakah investment opportunity set berpengaruh terhadap nilai perusahaan manufaktur yang terdaftar di Bursa Efek Indonesia Tahun 2016 - 2018??

\section{Tujuan Penelitian}

Sesuai dengan pokok permasalahan diatas, maka tujuan dari penelitian ini adalah:

1. Untuk menguji dan memperoleh bukti empiris pengaruh kepemilikan manajerial terhadap nilai perusahaan manufaktur yang terdaftar di Bursa Efek Indonesia Tahun 2016- 2018.

2. Untuk menguji dan memperoleh bukti empiris pengaruh kepemilikan institusional terhadap nilai perusahaan nilai perusahaan manufaktur yang terdaftar di Bursa Efek Indonesia Tahun 2016- 2018.

3. Untuk menguji dan memperoleh bukti empiris pengaruh kebijakan dividen terhadap nilai perusahaan nilai perusahaan manufaktur yang terdaftar di Bursa Efek Indonesia Tahun 2016- 2018.

4. Untuk menguji dan memperoleh bukti empiris pengaruh investment 
opportunity set terhadap nilai perusahaan nilai perusahaan manufaktur yang terdaftar di Bursa Efek Indonesia Tahun 2016- 2018.

\section{TINJAUAN PUSTAKA}

\section{Teori Keagenan (Agency Theory)}

Salah satu teori yang berhubungan dengan kepemilikan manajerial dan kepemilikan Institusional adalah teori keagenan (agency theory). Agensi teori mengakibatkan hubungan yang asimetri antara pemilik dan pengelola, untuk menghindari terjadi hubungan yang asimetri tersebut dibutuhkan struktur kepemilikan yaitu kepemilikan manajerial dan kepemilikan institusional yang bertujuan untuk menjadikan perusahaan menjadi lebih sehat. Masalah keagenan pada awalnya dieksplorasi oleh Ross (1973), sedangkan eksplorasi teoritis secara mendetail dari teori keagenan pertama kali dinyatakan oleh Jensen and Mecking (1976) menyebutkan manajer suatu perusahaan sebagai "agen" dan pemegang saham "principal".

\section{Teori Signal (Signalling Theory)}

Brigham dan Houston (2011) teori signal adalah suatu tindakan yang diambil perusahaan untuk memberi petunjuk bagi investor tentang bagaimana manajemen memandang prospek perusahaan untuk masa mendatang. Teori signal menunjukan adanya asimetri informasi antara manajemen perusahaan dan pihakpihak yang berkepentingan dengan informasi tersebut. Dorongan perusahaan untuk memberikan informasi karena terdapat asimetri informasi antara perusahaan dan pihak luar karena perusahaan mengetahui lebih banyak mengenai perusahaan dan prospek yang akan datang dari pada pihak luar (investor dan kreditor).

\section{Kepemilikan Manjerial}

Menurut Pujiati dan Widanar (2009) kepemilikan manajerial adalah proporsi pemegang saham dari pihak manajemen yang secara aktif ikut dalam pengambilan keputusan perusahaan (direktur dan komisaris). Christiawan dan Tarigan (2007) menyatakan kepemilikan manajerial menunjukkan adanya peran ganda seorang manajer, yaitu sebagai seorang manajer sekaligus pemegang saham, dirinya tidak ingin perusahaan mengalami kesulitan keuangan atau bahkan kebangkrutan.

\section{Kepemilkan Institusional}

Jensen dan Meckling (1976) menyatakan bahwa kepemilikan institusional memiliki peranan yang sangat penting dalam meminimalisasi konflik keagenan yang terjadi antara manajer dan pemegang saham. Keberadaan investor institusional dianggap mampu menjadi mekanisme monitoring yang efektif dalam setiap keputusan yang diambil oleh manajer.

\section{Kebijakan Dividen \\ Salah satu return yang akan diperoleh para pemegang saham adalah dividen. Dividen merupakan bagian dari suatu keuntungan yang dibayarkan oleh perusahaan. Jadi kebijakan dividen adalah keputusan apakah laba yang diperoleh perusahaan akan dibagikan kepada pemegang saham sebagai dividen atau akan ditahan dalam bentuk laba ditahan guna pembiayaan investasi dimasa mendatang.}




\section{Investment Opportunity Set}

Menurut (Sudiani dan Darmyanti, 2016) memperkenalkan investment opportunity set (IOS) dalam kaitannya untuk mencapai tujuan perusahaan. Menurutnya investment opportunity set memberikan petunjuk yang lebih luas dimana nilai perusahaan sebagai tujuan utama tergantung pada pengeluaran perusahaan di masa yang akan datang dengan nilai/return sebagai hasil dari keputusan investasi untuk menghasilkan nilai perusahaan.

\section{Nilai Perusahaan}

Nilai perusahaan yang tinggi menimbulkan semangat pemegang saham untuk meningkatkan kekayaan, dengan begitu permintaan terhadap saham akan meningkat. Harga saham yang lebih tinggi akan membuat nilai saham perusahaan meningkat. Brigham (2001) berpendapat bahwa nilai perusahaan sangat penting karena nilai perusahaan yang tinggi akan diikuti oleh tingginya kemakmuran pemegang saham.

\section{Kerangka Berpikir}

Nilai perusahaan adalah harga sebuah saham yang telah beredar di pasar saham yang harus dibayar oleh investor untuk dapat memiliki sebuah perusahaan. Untuk mengurangi agency cost, dapat dilakukan dengan meningkatkan kepemilikan manajerial. Kepemilikan manajerial merupakan jumlah saham yang dimiliki oleh manajemen dari seluruh modal saham dalam perusahaan.

Selain kepemilikan manajerial ada juga yang namanya kepemilikan Institusional dimana kepemilikan institusional adalah kepemilikan saham perusahaan yang dimiliki oleh institusi atau Lembaga. Meningkatkan nilai perusahaan juga berdasarkan kebijakan dividen, pembagian dividen yang tinggi dapat meningkatkan nilai perusahaan. Pembayaran dividen yang wajar oleh perusahaan akan mendapatkan kepercayaan yang tinggi dari investor dan hal ini dapat membantu memelihara nilai perusahaan. Nilai sebuah perusahaan dapat diukur dengan menggunakan investment opportunity set. Investment opportunity set (IOS) merupakan nilai perusahaan yang besarnya tergantung pada pengeluaran-pengeluaran yang ditetapkan manajemen dimasa yang akan datang

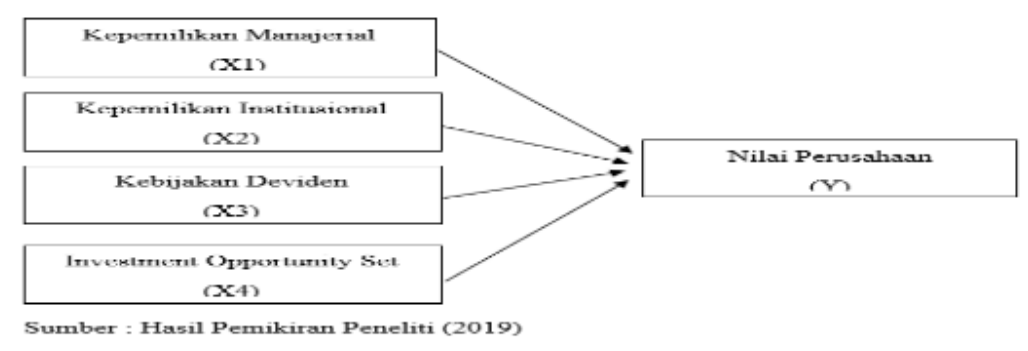

Gambar 3.1

Kerangka Pemikiran

Sumber: Hasil pemikiran peneliti (2019) 


\begin{abstract}
Hipotesis
Pengaruh Kepemilikan Manajerial terhadap Nilai Perusahaan

Menurut Pujiati dan Widanar (2009) kepemilikan manajerial adalah proporsi pemegang saham dari pihak manajemen yang secara aktif ikut dalam pengambilan keputusan perusahaan (direktur dan komisaris). Kepemilikan manajerial diasumsikan sebagai mekanisme pengendalian internal dan berfungsi sebagai monitoring positif untuk mengurangi konflik keagenan. Temuan tersebut diperkuat oleh penelitian Ningsih (2013) yang menemukan bahwa variabel kepemilikan manajerial juga berpengaruh positif pada nilai perusahaan.

Hal ini berarti bahwa semakin tinggi proporsi kepemilikan manajerial, maka nilai perusahaan juga akan terus meningkat. Hasil penelitian ini konsisten dengan hasil penelitian Abbas (2013) yang menyatakan bahwa meningkatnya kepemilikan manajerial berdampak positif pada nilai perusahaan.
$\mathrm{H}_{1}$ : kepemilikan manajerial berpengaruh positif terhadap nilai perusahaan.

\begin{tabular}{l} 
Pengaruh \\
Institusional terhadap Nilai \\
Perusahaan \\
\multicolumn{1}{c}{ Kepemilikan $\quad$ institusional }
\end{tabular}
merupakan kepemilikan sebuah perusahaan yang dimiliki oleh suatu badan atau pemilik institusional, seperti pemerintah, asuransi dan bank. Tingginya jumlah kepemilikan institusional akan meningkatkan sistem kontrol perusahaan yang ditujukan guna meminimalisasi tingkat kecurangan akibat tindakan oportunistik pihak manajer yang nantinya dapat mengurangi nilai perusahaan. Astrini (2014) yang menyatakan bahwa kepemilikan institusional berpengaruh positif pada nilai perusahaan. Temuan ini sejalan dengan temuan Nuriana (2012), yaitu bahwa kepemilikan institusional berpengaruh positif pada nilai perusahaan manufaktur yang terdaftar di Bursa Efek Indonesia. Semakin tinggi kepemilikan institusional, semakin efektif pengawasan pemegang saham pada perusahaan untuk mengurangi agency cost dan meningkatkan nilai perusahaan.

$\mathrm{H}_{2}$ : kepemilikan institusional berpengaruh positif terhadap nilai perusahaan

\section{Pengaruh Kebjakan Dividen terhadap Nilai Perusahaan}

Kebijakan dividen adalah keputusan apakah laba yang diperoleh perusahaan akan dibagikan kepada pemegang saham sebagai dividen atau akan ditahan dalam bentuk laba ditahan guna pembiayaan investasi di masa yang akan datang, kebijakan dividen juga dapat dianggap sebagai salah satu komitmen perusahaan untuk membagikan sebagian laba bersih yang diterima kepada para pemegang saham, kebijakan dividen akan berdampak terhadap besarnya laba ditahan perusahaan yang merupakan sumber pendanaan internal perusahaan yang akan digunakan untuk mengembangkan perusahaan di masa yang akan. Dengan membayarkan dividen kepada para pemegang saham akan menaikkan nilai perusahaan. Kenaikan pembayaran dividen dilihat sebagai sinyal bahwa perusahaan memiliki prospek yang baik. Penelitian pengaruh kebijakan dividen terhadap nilai perusahaan yang dikemukakan oleh Senata (2016), Hilal (2014) sama-sama menyebutkan 
bahwa kebijakan deviden berpengaruh positif terhadap nilai perusahaan.

$\mathrm{H}_{3}$ : Kebijakan dividen berpengaruh positif terhadap nilai perusahaan.

\section{Pengaruh Investment Opportunity Set terhadap Nilai Perusahaan}

Investment Opportunity Set (IOS) merupakan pilihan kesempatan investasi masa depan yang dapat mempengaruhi pertumbuhan aktiva perusahaan atau proyek yang memiliki net present value positif. Sehingga IOS memiliki peranan yang sangat penting bagi perusahaan karena IOS merupakan keputusan investasi dalam bentuk kombinasi dari aktiva yang dimiliki (assets in place) dan opsi investasi di masa yang akan datang, dimana IOS tersebut akan mempengaruhi nilai suatu perusahaan (Pangalung, 2003). Kallapur dan Trombley (2001) menyatakan bahwa kesempatan investasi perusahaan merupakan komponen penting dari nilai pasar.. Penelitian Rachmawati dan Triatmoko (2007), Astrini (2014), Putra (2019), Syardiana, dkk (2015) dan Sulistiono (2016) membuktikan bahwa Investment Opportunity Set berpengaruh positif terhadap nilai perusahaan.

$\mathrm{H}_{4}$ : Investment opportunity set berpengaruh positif terhadap nilai perusahaan.

\section{METODE PENELITIAN}

Lokasi penelitian merupakan suatu tempat atau wilayah dimana penelitian tersebut dilakukakan. Penelitian ini dilakukan di PT Bursa Efek Indonesia (BEI), dengan mengakses www.idx.co.id. Obyek penelitian dalam hal ini adalah Kepemilikan Manajerial, Kepemilkan Institusional, Kebijakan Dividen dan
Invesment Opportunity Set terhadap Nilai Perusahaan

\section{Kepemilikan Manajerial}

Variabel Independen yang digunakan adalah kepemilikan manajerial. Kepemilikan manajerial diukur berdasarkan persentase kepemilikan saham oleh institutsi perusahaan. Rumus untuk menghitung persentase kepemilikan manajerial berdasarkan penelitian Sartono (2010:487) adalah sebagai berikut Kepemilikan Manjerial $=\frac{\text { Jumlah Saham Manajerial }}{\text { Jumlah Saham Yang Beredar }}$ X 100\% .........(1)

\section{Kepemilikan Institusional}

Kepemilikan institusional diukur sesuai persentase kepemilikan saham oleh institusi perusahaan. Rumus untuk menghitung persentase kepemilikan institusional berdasarkan penelitian Sartono (2010:487) adalah sebagai berikut:

Kepemilikan Institusional $=\frac{\text { Jumlah Saham Institusional }}{\text { Jumlah Saham Yang Beredar }} \times 100 \% \ldots \ldots(2)$

\section{Kebijakan Dividen}

Kebijakan Deviden adalah suatu kebijakan perusahaan yang berhubungan dengan penentuan persentase laba bersih perusahaan yang dibagikan sebagai dividen kepada pemegang saham (Ningrum, 2006). Kebijakan dividen dalam penelitian ini menggunakan indikator Dividend Payout Ratio (DPR). Secara matematis, indikator kebijakan dividen dapat dinyatakan sebagai berikut:

$D P R=\frac{\text { Deviden per lembar saham }}{\text { Laba per saham beredar }}$

\section{Investment Opportunity Set}

Secara umum dapat dikatakan bahwa Investment Opportunity Set menggambrakan tentang luasnya kesempatan atau peluang investasi bagi suatu prusahaan, namun sangat 
tergantung pada pilihan expenditure perusahaan untuk kepentingan di masa yang akan datang. Mengacu dari penenelitian Wulansari (2013) Investment Opportunity Set dalam penelitian ini diukur dengan menggunakan Market Value to Book Value of Assets Ratio (MVBVA) MVBVA $=\frac{\text { Total Asset }- \text { Total Ekuitas }+ \text { (Jumlah Saham Beredar X Closing Price })}{\text { Total Asset }} \ldots(4$

\section{Nilai Perusahaan}

Nilai Perusahaan (NP) adalah nilai suatu perusahaan yang dapat memberikan kemakmuran kepada pemegang saham secara maksimum apabila harga saham meningkat. Semakin tinggi harga saham, maka semakin tinggi tingkat kemakmuran dari pemegang saham. Rasio ini mengukur nilai yang diberikan pasar keuangan kepada manajemen dan organisasi perusahaan sebagai sebuah perusahaan yang terus tumbuh (Brigham, 1999: 92). Cara mengukurnya dengan rumus :

$$
P B V=\frac{\text { Harga Pasar Per lembar Saham }}{\text { Nilai Buku Saham }} \ldots \ldots \ldots \ldots \ldots \ldots \text { (5) }
$$

\section{Analisis Statistik Deskriptif}

Statistik deskriptif adalah statistik yang digunakan untuk menganalisis data dengan cara mendeskripsikan atau menggambarkan data yang telah terkumpul sebagaimana adanya tanpa bermaksud membuat kesimpulan yang berlaku untuk umum atau generalisasi (Sugiyono, 2017:147). Termasuk dalam statistik deskriptif antara lain seperti penyajian data melalui tabel, grafik, diagram, lingkaran pictogram, perhitungan modus, median dan mean (pengukuran tendensi rendah), perhitungan rata-rata, standar deviasi, dan perhitungan persentase. Statistik deskriptif yang digunakan dalam penelitian ini adalah nilai minimum, maksimum, rata-rata dan standar deviasi.

\section{Uji Asumsi Klasik}

\section{1) Uji Normalitas}

Menurut Ghozali (2016:154) uji normalitas dilakukan untuk menguji apakah dalam model regresi variabel independen dan variabel dependen atau keduanya mempunyai distribusi normal atau tidak. Apabila variabel tidak berdistribusi secara normal maka hasil uji stastistik akan mengalami penurunan. Uji normalitas data dapat dilakukan dengan One Sample Kolmogorov Smirnov yaitu dengan ketentuan apabila nilai signifikan diatas 0,05 maka data terdistribusi normal. Sedangkan jika hasil One Sample Kolmogorov Smirnov menunjukkan nilai signifikan dibawah 0.05 maka data tidak terdistribusi normal.

\section{2) Uji Multikolinieritas}

Uji multikolinieritas bertujuan untuk mengetahui apakah dalam model regresi ditemukan adanya korelisasi antar variabel bebas. Model regresi yang baik seharusnya tidak terjadi korelasi antara variabel bebas. Untuk mengetahui ada atau tidaknya multikolininiertas maka dapat dilihat dari nilai Varians Inflaction Faktor (VIF). Bila angka VIF ada yang melebihi 10 berarti terjadi multikolinieritas (Ghozali,2016:103).

\section{3) Uji Autokorelasi}

Uji autokorelasi bertujuan untuk menguji apakah dalam model regresi ada korelasi antara kesalahan pengganggu pada periode $\mathrm{t}$ dengan kesalahan pengganggu pada periode t1 (sebelumnya) (Ghozali, 2016:108). Model regresi yang baik adalah regresi yang bebas dari autokorelasi. Alat ukur yang digunakan untuk mendeteksi adanya autokorelasi dalam penelitian ini menggunakan uji Durbin-Watson (DW), dengan kriteria hasil: (1) bila nilai DW antara du dan 
(4-du) berarti tidak terjadi autokorelasi, (2) bila DW < dl berarti terjadi autokorelasi positif, (3) bila DW > (4-dl) berarti terjadi autokorelasi negatif, (4) bila DW antara (4-du) dan (4-dl) berarti hasil tidak dapat disimpulkan.

\section{4) Uji Heteroskedastisitas}

Uji heteroskedastisitas bertujuan untuk mengetahui apakah ada model regresi ini terjadi ketidaksamaan varian dari residu satu pengamatan ke pengamatan lain. Jika varian dari residu pengamatan ke pengamatan lain berbeda berarti ada gejala heteroskedastisitas dalam model regresi tersebut. Model regresi yang baik tidak terjadi adanya heteroskedastisitas. Dalam penelitian ini uji heteroskedastisitas menggunakan uji glejzer. Uji glejzer dilakukan dengan membuat model regresi yang mellibatkan nilai absolute residual, yaitu dengan meregresikan nilai absolute residual dengan variabel independen (Ghozali,2016:134). Kriteria yang digunakan adalah jika probabilitas $>0,05$ maka tidak terjadi heteroskedastisitas.

\section{Analisis Regresi Berganda} $\mathrm{NP}=\alpha+\beta 1 \mathbf{K m}+\beta 2 \mathrm{Ki}+\beta 3 \mathbf{K d}+$ B4Ios + e

Keterangan:

$\mathrm{NP}=$ Nilai Perusahaan

$\mathrm{KM}=$ Kepemilikan Manajerial

$\mathrm{KI}=$ Kepemilkan Institusional

$\mathrm{KD}=$ Kebijakan Deviden

$\mathrm{IOS}=$ Investment Opportunity Set

$\beta 1=$ Koefisien Regresi Variabel Kepemilikan Manajerial

$\beta 2=$ Koefisien Regresi Variabel Kepemilikan Institusional

$\beta 3=$ Koefisien Regresi Variabel Kebijakan Deviden

$\beta 4=$ Koefisien Regresi Variabel Investment Opportunity Set $\alpha=$ Konstanta

$\mathrm{e}=$ eror

\section{Uji Kelayakan Model}

1) Uji Koefisien Determinasi $\left(\mathbf{R}^{2}\right)$

Koefisien Determinasi $\left(\mathrm{R}^{2}\right)$ bertujuan untuk menguji tingkat keeratan atau keterikatan antara variabel dependen dan variabel independen yang bisa dilihat dari besarnya nilai koefisien determinasi (Adjusted R-Square). Nilai $R$-Square yang kecil berarti kemampuan variabel independen dalam menjelaskan variabel dependen sangat terbatas. Nilai yang mendekati satu artinya variabel independen memberikan hampir semua informasi yang dibutuhkan dalam memprediksi variabel dependen (Ghozali, 2016:97).

2) Uji F

Menurut Ghozali (2016:96), uji statistik F pada dasarnya menunjukkan apakah semua variabel independen yang dimasukkan dalam model memiliki pengaruh secara bersamasama terhadap variabel dependen. Uji $F$ juga digunakan untuk menguji apakah model regresi fit dengan data observasinya. Adapun kriteria pengambilan keputusan: jika nilai sig $<0,05$, maka model dikatakan fit dengan data observasinya

3) Uji t

Menurut Ghozali (2016:97), uji t digunakan untuk menguji signifikansi tiap-tiap variabel bebas terhadap variabel terikatnya secara parsial. Dalam pengujian ini tingkat signifikan tiap-tiap variabel bebas (sig t) dibandingkan dengan (alpha) 5\%. Jika sig $\mathrm{t} \leq 5 \%$ maka $\mathrm{H} 1, \mathrm{H} 2$ diterima, artinya tiap-tiap variabel independen berpengaruh signifikan terhadap variabel dependen. Adapun kriteria pengambilan keputusan sebagai berikut:

Jika $\operatorname{sig}(a) \leq 0,05$, maka H1 diterima 
Journal of Applied Management and Accounting Science ( J A M A S )

(Ni Nyoman Yuningsih, Ni Luh Gde Novitasari 76 - 91)

Vol 1, No 2, Juli 2020

Jika sig (a) > 0,05, maka H1 ditolak.

\section{HASIL DAN PEMBAHASAN}

\section{Hasil Analisis}

\section{Analisis Statistik Deskriptif}

Statistik Deskriptif dalam penelitian ini digunakan untuk memberikan informasi mengenai variabel-variabel penelitian seperti kepemilikan manajerial kepemilikan institusional, kebijakan dividen, investment opportunity set dan nilai perusahaan. Statistik deskriptif untuk variabelvariabel penelitian tersebut dapat dilihat sebagai berikut:

Tabel 5.1

\section{Hasil Statistik Deskriptif}

Descriptive Statistics

\begin{tabular}{|c|c|c|c|c|c|}
\hline & $\mathrm{N}$ & Minimum & Maximum & Mean & Std. Deviaion \\
\hline $\mathrm{KM}$ & 54 & .0000 & .2522 & .062496 & .0924854 \\
$\mathrm{KI}$ & 54 & .7478 & 1.0000 & .937550 & .0925132 \\
$\mathrm{KD}$ & 54 & .0741 & 4.9180 & .543615 & .7887043 \\
$\mathrm{IOS}$ & 54 & .5188 & 3.8557 & 1.794206 & .8808970 \\
$\mathrm{NP}$ & 54 & .4196 & 7.0217 & 2.560763 & 1.7291819 \\
Valid N (listwise) & 54 & & & & \\
\hline
\end{tabular}

\section{Hasil Uji Asumsi Klasik}

\section{1) Uji Normalitas}

Uji normalitas dilakukan untuk menguji apakah dalam model regresi variabel independen dan variabel dependen atau keduanya mempunyai distribusi normal atau tidak. Apabila variabel tidak berdistribusi secara normal maka hasil uji stastistik akan mengalami penurunan. Uji normalitas data dapat dilakukan dengan One
Sample Kolmogorov Smirnov yaitu dengan ketentuan apabila nilai signifikan diatas 0,05 maka data terdistribusi normal. Sedangkan jika hasil One Sample Kolmogorov Smirnov menunjukkan nilai signifikan dibawah 0.05 maka data tidak terdistribusi normal. Hasil Uji Normalitas ditunjukkan pada Tabel 5.2 sebagai berikut

Tabel 5.2

\section{Hasil Uji Normalitas}

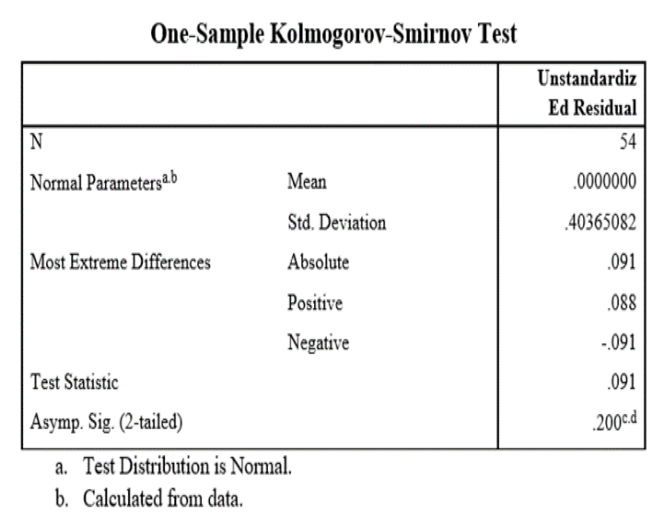




\section{2) Uji Multikolinieritas}

Uji multikolinearitas bertujuan untuk mengetahui apakah dalam model regresi ditemukan adanya korelasi antar variabel bebas. Model regresi yang baik seharusnya tidak terjadi korelasi antar variabel bebas. Untuk mengetahui ada atau tidaknya multikolinearitas maka dapat dilihat dari nilai Tolerance atau Varians Inflation Faktor (VIF), bila Tolerance $>0,10$ atau VIF $<10$ berarti tidak terjadi multikolinearitas. Hasil Uji Multikolinearitas disajikan pada Tabel 5.3 berikut ini:

Tabel 5.3

Hasil Uji Multikolinieritas

Coefficients $^{\mathrm{a}}$

\begin{tabular}{|c|c|c|c|c|c|c|c|c|}
\hline \multirow[b]{2}{*}{ Mode } & & \multicolumn{2}{|c|}{$\begin{array}{l}\text { Unstandardized } \\
\text { Coefficients }\end{array}$} & \multirow{2}{*}{\begin{tabular}{|c|}
$\begin{array}{c}\text { Unstandardized } \\
\text { Coefficients }\end{array}$ \\
Beta \\
\end{tabular}} & \multirow[b]{2}{*}{$t$} & \multirow[b]{2}{*}{ Sig. } & \multicolumn{2}{|c|}{ Collinearity Statistic } \\
\hline & & $B$ & Std.Error & & & & Tolerance & VIF \\
\hline 1 & (Constant) & .002 & .420 & & .004 & .997 & & \\
\hline & $\mathrm{KM}$ & -.757 & .770 & -.040 & -.983 & .331 & .655 & 1.527 \\
\hline & $\mathrm{KI}$ & -.876 & .441 & -.079 & -1.986 & .053 & .691 & 1.447 \\
\hline & $\mathrm{KD}$ & .034 & .074 & .015 & .453 & .653 & .961 & 1.040 \\
\hline & IOS & 1.901 & .068 & .986 & 28.107 & .000 & .880 & 1.137 \\
\hline
\end{tabular}

3) Uji Autokorelasi

Uji autokorelasi bertujuan untuk melihat apakah dalam suatu model regresi linier terdapat korelasi antara kesalahan pengganggu pada periode $t$ dengan kesalahan pengganggu pada periode $\mathrm{t}-1$ (sebelumnya). Model regresi yang baik adalah regresi yang bebas dari auto korelasi dengan ketentuan $\mathrm{du}<\mathrm{dw}<4-\mathrm{du}$. Hasil uji autokorelasi dapat dilihat pada tabel 5.4 berikut ini:

Tabel 5.4

\section{Hasil Uji Auotokorelasi}

\begin{tabular}{|c|c|c|c|c|c|}
\hline \multicolumn{6}{|c|}{ Model Summary } \\
\hline Model & $\mathrm{R}$ & R Square & $\begin{array}{c}\text { Adjusted R } \\
\text { Square }\end{array}$ & $\begin{array}{l}\text { Std. Error of } \\
\text { the Estimate }\end{array}$ & $\begin{array}{l}\text { Durbin- } \\
\text { Waston }\end{array}$ \\
\hline 1 & $.973^{\mathrm{a}}$ & .947 & .943 & .4196198 & 2.024 \\
\hline
\end{tabular}

\section{4) Uji Heteroskedastisitas}

Uji heteroskedastisitas bertujuan untuk mengetahui apakah ada model regresi ini terjadi ketidaksamaan varian dari residu satu pengamatan ke pengamatan lain. Jika varian dari residu pengamatan ke pengamatan lain berbeda berarti ada gejala heteroskedastisitas dalam model regresi tersebut. Hasil uji heteroskedastisitas disajikan pada Tabel 5.5 berikut ini: 


\section{Tabel 5.5}

\section{Hasil Uji Heteroskedastisitas}

\section{Coefficients $^{\mathrm{a}}$}

\begin{tabular}{|c|c|c|c|c|c|c|}
\hline \multirow[b]{2}{*}{ Mode } & & \multicolumn{2}{|c|}{$\begin{array}{l}\text { Unstandardized } \\
\text { Coefficients }\end{array}$} & \multirow{2}{*}{$\begin{array}{c}\text { Unstandardized } \\
\text { Coefficients }\end{array}$} & \multirow[b]{2}{*}{$\mathrm{t}$} & \multirow[b]{2}{*}{ Sig. } \\
\hline & & $\mathrm{B}$ & Std.Error & & & \\
\hline \multirow[t]{5}{*}{1} & (Constant) & 100.127 & 140.202 & & .714 & .478 \\
\hline & $\mathrm{KM}$ & -262.410 & 257.200 & -.178 & -1.020 & .313 \\
\hline & $\mathrm{KI}$ & -102.744 & 147.322 & -.118 & -.697 & .489 \\
\hline & $\mathrm{KD}$ & 6.665 & 24.804 & .039 & .269 & .789 \\
\hline & IOS & 15.628 & 22.596 & .104 & .692 & .492 \\
\hline
\end{tabular}

\section{Hasil Uji Regresi Linier Berganda}

Tabel 5.6

Hasil Uji Analisis Linier Berganda

Coefficients ${ }^{\mathrm{a}}$

\begin{tabular}{|c|c|c|c|c|c|c|c|c|}
\hline \multirow[b]{2}{*}{ Mode } & & \multicolumn{2}{|c|}{$\begin{array}{l}\text { Unstandardized } \\
\text { Coefficients }\end{array}$} & \multirow{2}{*}{$\begin{array}{c}\text { Unstandardized } \\
\text { Coefficients }\end{array}$} & & \multirow[b]{2}{*}{ Sig. } & \multicolumn{2}{|c|}{ Collinearity Statistic } \\
\hline & & $B$ & Std.Error & & & & Tolerance & VIF \\
\hline 1 & (Constant) & .002 & .420 & & .004 & .997 & & \\
\hline & $\mathrm{KM}$ & .757 & .770 & .040 & .983 & .331 & .655 & 1.527 \\
\hline & $\mathrm{KI}$ & .876 & .441 & .079 & -1.986 & .053 & .691 & 1.447 \\
\hline & $\mathrm{KD}$ & .034 & .074 & .015 & .453 & 653 & .961 & 1.040 \\
\hline & IOS & 1.901 & .068 & .986 & 28.107 & .000 & .880 & 1.137 \\
\hline
\end{tabular}

a. Dependent Variable: NP

$\mathrm{NP}=0,002-0,757 \mathrm{KM}-0,876 \mathrm{KI}+$ $0,034 \mathrm{KD}+1,901 \mathrm{IOS}$

Arti dari persamaan regresi diatas dapat dijelaskan sebagai berikut :

1) Nilai konstanta sebesar 0,002 berarti bahwa jika seluruh variabel bebas dinyatakan konstan pada angka 0 (nol), maka nilai perusahaan sebesar 0,002 persen.

2) Nilai koefisien investment opportunity set (IOS) sebesar
1,901 artinya apabila investment opportunity set (IOS) meningkat 1 satuan, maka nilai perusahaan meningkat sebesar 1,901 persen dengan asumsi variabel bebas lainnya konstan.

\section{Hasil Uji Kelayakan Model}

1) Koefisien Determinasi ( $\mathbf{R}^{2}$ )

Tabel 5.7

Hasil Uji Koefisien Determinasi

Model Summary
\begin{tabular}{|c|c|c|c|c|c|}
\hline Model & R & R Square & $\begin{array}{c}\text { Adjusted R } \\
\text { Square }\end{array}$ & $\begin{array}{c}\text { Std. Error of } \\
\text { the Estimate }\end{array}$ & $\begin{array}{c}\text { Durbin- } \\
\text { Waston }\end{array}$ \\
\hline 1 & $.973^{\mathrm{a}}$ & .947 & .943 & .4196198 & 2.024 \\
\hline
\end{tabular}
$\begin{aligned} & \text { a. Predictors : (Constant), IOS, KI, KD, KM } \\
& \text { b. Dependent Variable : NP }\end{aligned}$


Berdasarkan Tabel 5.8 diperoleh nilai Adjusted R2 sebesar 0,943. Hal ini menunjukkan bahwa 94,3\% variabel Nilai Perusahaan dipengaruhi oleh Kepemikan manajerial, Kepemilikan Institusonal (KI), Kebijakan Dividen
(KD), dan Investment Opportunity Set (IOS) sedangkan sisanya sebesar $5,7 \%$ dipengaruhi oleh variabel lain diluar penelitian ini.

2) Uji Simultan ( Uji F )

Tabel 5.8

Hasil Uji Simultan F

\begin{tabular}{|c|c|c|c|c|c|c|}
\hline \multicolumn{7}{|c|}{ ANOVA $^{a}$} \\
\hline & & $\begin{array}{l}\text { Sum of } \\
\text { Aquares }\end{array}$ & df & $\begin{array}{l}\text { Mean } \\
\text { Square }\end{array}$ & $\mathrm{F}$ & Sig. \\
\hline 1 & $\begin{array}{l}\text { Regression } \\
\text { Residual } \\
\text { Total }\end{array}$ & $\begin{array}{l}154.132 \\
8.628 \\
167.760\end{array}$ & $\begin{array}{l}4 \\
49 \\
53\end{array}$ & $\begin{array}{l}38.533 \\
.176\end{array}$ & 218.837 & $.000^{\mathrm{b}}$ \\
\hline
\end{tabular}

Tabel 5.8 menunjukkan bahwa nilai $\mathrm{F}$ hitung sebesar 218,837 dengan tingkat signifikansi sebesar 0,000 lebih kecil dari 0,05 sehingga dapat disimpulkan bahwa Kepemilikan Manajerial, Kepemilikan Institusional, Kebijakan Dividen dan Investment Opportunity Set secara bersama-sama berpengaruh terhadap Nilai
Perusahaan pada perusahaan yang terdaftar di Bursa Efek Indonesia periode 2016 - 2018 diterima. Hasil ini berarti model yang dihipotesiskan sesuai (Fit) atau model tersebut mampu untuk menjelaskan data sampel yang ada..

3) Uji t

Tabel 5.9

\section{Hasil Uji Signifikansi Parameter Indivudual}

Coefficients $^{\mathrm{a}}$

\begin{tabular}{|c|c|c|c|c|c|c|c|c|}
\hline \multirow{2}{*}{\multicolumn{2}{|c|}{ Model }} & \multicolumn{2}{|c|}{$\begin{array}{l}\text { Unstandardized } \\
\text { Coefficients }\end{array}$} & \multirow{2}{*}{$\begin{array}{c}\begin{array}{c}\text { Unstandardized } \\
\text { Coefficients }\end{array} \\
\text { Beta }\end{array}$} & \multirow[b]{2}{*}{$\mathrm{t}$} & \multirow[b]{2}{*}{ Sig. } & \multicolumn{2}{|c|}{ Collinearity Statistic } \\
\hline & & $\mathrm{B}$ & Std.Error & & & & Tolerance & VIF \\
\hline \multirow[t]{5}{*}{1} & (Constant) & .002 & .420 & & .004 & .997 & & \\
\hline & $\mathrm{KM}$ & -.757 & .770 & -.040 & -.983 & .331 & .655 & 1.527 \\
\hline & $\mathrm{KI}$ & -.876 & .441 & -.079 & -1.986 & .053 & .691 & 1.447 \\
\hline & $\mathrm{KD}$ & .034 & .074 & .015 & .453 & .653 & .961 & 1.040 \\
\hline & IOS & 1.901 & .068 & .986 & 28.107 & .000 & .880 & 1.137 \\
\hline
\end{tabular}

Berdasarkan hasil signifikansi parameter individual (Uji t) dapat dijelaskan sebagai berikut :

a) Hasil analisis menunjukkan kepemilikan manajerial memiliki nilai koefisien regresi sebesar $-0,757$ dan nilai $t$ hitung sebesar $-0,983$ dengan nilai signifikansi sebesar 0,331 lebih besar dari 0,05 yang berarti kepemilikan manajerial tidak berpengaruh terhadap nilai perusahaan sehingga $\mathrm{H} 1$ ditolak.

b) Hasil analisis menunjukkan kepemilikan institusional memiliki nilai koefisien regresi sebesar $-0,876$ dan nilai $\mathrm{t}$ hitung sebesar $-1,986$ dengan nilai signifikansi sebesar 0,053 lebih besar dari 0,05 yang berarti 
kepemilikan institusional tidak berpengaruh terhadap nilai perusahaan sehingga $\mathrm{H} 2$ ditolak.

c) Hasil analisis menunjukkan kebijakan dividen memiliki nilai koefisien regresi sebesar $-0,034$ dan nilai $t$ hitung sebesar 0,453 dengan nilai signifikansi sebesar 0,653 lebih besar dari 0,05 yang berarti kebijakan dividen tidak berpengaruh terhadap nilai perusahaan sehingga $\mathrm{H} 3$ ditolak.

d) Hasil analisis menunjukkan investment opportunity set memiliki nilai koefisien regresi sebesar 1,901 dan nilai $\mathrm{t}$ hitung sebesar 28,107 dengan nilai signifikansi sebesar 0,000 lebih kecil dari 0,05 yang berarti investment opportunity set berpengaruh positif terhadap nilai perusahaan sehingga $\mathrm{H} 4$ diterima.

\section{SIMPULAN DAN SARAN}

\section{Simpulan}

Pengaruh Kepemilikan Manajerial terhadap Nilai Perusahaan

Hipotesis pertama menyatakan kepemilikan manajerial berpengaruh positif terhadap nilai perusahaan. Berdasarkan hasil uji t dapat dilihat bahwa signifikansi variabel kepemilikan manajerial sebesar 0,331 lebih besar dari taraf nyata 0.05 . Hasil ini menyatakan bahwa kepemilkan manajerial tidak berpengaruh terhadap nilai perusahaan sehingga hipotesis pertama dalam penelitian ini ditolak. Hasil penelitian ini konsisten dengan penelitian Permanasari (2010), Sasurya dan Asandimitra (2013), Wida dan Suartana (2014) yang menyatakan kepemilikan manajerial tidak berpengaruh terhadap nilai perusahaan.

\section{Pengaruh Kepemilikan \\ Institusional terhadap Kinerja Perusahaan}

Hipotesis kedua menyatakan kepemilikan Institusional berpengaruh positif terhadap nilai perusahaan. Berdasarkan hasil uji $t$ dapat dilihat bahwa signifikansi variabel kepemilikan Institusional sebesar 0,053 lebih besar dari taraf nyata 0.05 . Hasil ini menyatakan bahwa kepemilkan instutusioanl tidak berpengaruh terhadap nilai perusahaan sehingga hipotesis kedua dalam penelitian ini ditolak. Temuan ini mendukung penelitian Syifa (2015) dan Permanasari (2010) yang menyatakan bahwa kepemilikan institusional tidak berpengaruh terhadap nilai perusahaan.

\section{Pengaruh Kebijakan Dividen terhadap Nilai Perusahaan}

Hipotesis ketiga menyatakan kebijakan dividen berpengaruh positif terhadap nilai perusahaan. Berdasarkan hasil uji $\mathrm{t}$ dapat dilihat bahwa signifikansi variabel kebijakan dividen sebesar 0,653 lebih besar dari taraf nyata 0.05 . Hasil ini menyatakan bahwa kepemilkan instutusioanl tidak berpengaruh terhadap nilai perusahaan sehingga hipotesis ketiga dalam penelitian ini ditolak. Hasil penelitian ini juga mendukung penelitian Kharis dan Abrar (2016), Nurhayati (2013) yang menyatakan tidak terdapat pengaruh antara variabel kebijakan dividen terhadap nilai perusahaan.

\section{Pengaruh Investment Opportunity} Set terhadap Nilai Perusahaan

Hipotesis keempat menyatakan Investment Opportunity Set berpengaruh positif terhadap nilai perusahaan. Berdasarkan hasil uji $t$ dapat dilihat bahwa signifikansi variabel investment opportunity set sebesar 0,000 lebih kecil dari taraf 
nyata 0.05 . Hasil ini menyatakan bahwa investment opportunity set berpengaruh positif terhadap nilai perusahaan sehingga hipotesis keempat dalam penelitian ini diterima. Hasil penelitian ini juga didukung oleh penelitian Putra (2019) dan Astriani (2014) yang mengemukakan bahwa investment opportunity set berpengaruh terhadap nilai perusahaan.

\section{Saran}

Berdasarkan pembahasan dan kesimpulan penelitian yang telah diuraikan sebelumnya, maka saran yang diajukan untuk penelitian selanjutnya sebagai berikut:

1. Data yang digunakan dalam penelitian ini masih terbatas, hanya menggunakan satu industri yaitu perusahaan manufaktur yang terdaftar dalam Bursa Efek Indonesia (BEI). Rentan waktu yang digunakan adalah 3 tahun, 2016-2018. Untuk mendapatkan pengaruh yang konsisten dan hasil yang lebih komprehensif, penelitian selanjutnya dapat menggunakan periode waktu yang lebih panjang.

2. Penelitian ini masih terdapat variabel independen yang tidak berpengaruh terhadap nilai perusahaan yaitu kepemilkan manajerial, kepemilikan institusional, dan kebijakan dividen. Peneliti selanjutnya disarankan menambah variabel yang mempengaruhi nilai perusahaan seperti ukuran perusahaan dan profitabilitas.

3. Penelitian ini hanya menggunakan jenis perusahaan manufaktur sehingga hasil penelitian tidak digeneralisasi dengan perusahaan lain, oleh karena itu untuk penelitian selanjutnya diharapkan menggunakan semua jenis perusahaan di Bursa Efek Indonesia sehingga hasil penelitian dapat digeneralisir.

\section{DAFTAR PUSTAKA}

Abbas, Asad. 2013. Impact of Large Ownership on Firm Performance: A Case of non Financial Listed Companies of Pakistan. World Applied Sciences Journal, 21 (8), pp: 1141-1152.

Astriani. 2014. Pengaruh Kepemilikan Manajerial, Leverage, Profitabilitas, Ukuran Perusahaan Dan Investment Opportunity Set Terhadap Nilai Perusahaan. Skripsi. Universitas Negeri Padang.

Brigham, Eugene F. dan Houston, Joel F. 2011. Dasar-dasar Manajemen Keuangan Terjemahan. Edisi 10. Jakarta: Salemba Empat.

Brigham, Eugene F. and Joel F. Houston. 2001. Manajemen Keuangan (terjemahan). Buku 2. Edisi kedelapan. Erlangga. Jakarta.

Ghozali, Imam. 2016. Aplikasi Analisis Multivariate dengan Program IBM SPSS 23, Edisi 8. Semarang: Badan Penerbit Universitas Diponegoro.

Jensen, Michael. C dan Meckling, William H. (1976). Theory of The Firm: Managerial Behavior, Agency Costs and Ownership Structure. Journal 
of Financial Economics, V.3. No.4. pp 305-360.

Kallapur dan Trombley. 2001. The Assosiation Between Investment Opportunity Set Proxies And Realized Growth. Journal Of Bussines Finance And Accounting.

Ningrum, Nurika Samti Febriana. (2006). Analisis Pengaruh Keputusan Investasi, Keputusan Pendanaan, dan Kebijakan Dividen Terhadap Nilai Perusahaan Manufaktur di BEI. Tesis. Program Magister Manajemen STIE STIKUBANK Semarang

Ningsih, Hana Ratna. 2013. Pengaruh Kepemilikan Manajerial dan Rasio Pengembalian Aktiva Terhadap Nilai Perusahaan (Studi Kasus pada Industri Perbankan yang Terdaftar di Bursa Efek Indonesia). Jurnal Universitas Komputer Indonesia.

Nuraina, Elva. 2012. Pengaruh Kepemilikan Institusional dan Ukuran Perusahaan Terhadap Kebijakan Hutang dan Nilai Perusahaan (Studi pada Perusahaan Manufaktur yang Terdaftar di BEI). Jurnal Bisnis dan Ekonomi (JBE), 19 (2).

Pujiati dan Widanar. 2007. Pengaruh Struktur Kepemilikan terhadap Nilai Perusahaan: Keputusan Keuangan sebagai Variabel Intervening.Jurnal Perbanas, pp. 1- 24.
Ross. 1973. The Economic Theory of Agency: The Pricipal ${ }^{\text {ee }}$ s Problem. American Economics Review 63(2): 134139.

Rachmawati dan Hanung. 2007. Analisis Faktor-Faktor yang Mempengaruhi Kualitas Laba dan Nilai Perusahaan. Simposium Nasional Akuntansi X Makassar.

Sartono, R. Agus. 2010. Manajemen Keuangan. Yogyakarta: BPFE

Sudiani, N. K., \& Darmayanti, N. P. (2016). Pengaruh Profitabilitas, Likuiditas, Pertumbuhan, dan Investment Opportunity Set Terhadap Nilai Perusahaan. E-Jurnal Manajemen Unud, Vol.5 No.7 ISSN 2302-8912. Hal. 1-30.

Sasurya, Asandimitra. 2013. Pengaruh Kepemilikan Manajerial, Keputusan Investasi, Keputusan Pendanaan, Dan Kebijakan Deviden terhadap Nilai Perusahaan. E-Jurnal Universitas Negeri Surabaya Volume 6 No. 1.

Nurhayati, M. (2013). Profitabilitas, Likuiditas, dan Ukuran Perusahaan Pengaruhnya Terhadap Kebijakan Dividen dan Nilai Perusahaan Sektor Non Jasa. Jurnal Keuangan dan Bisnis, Vol. 5, No. 2.

Senata.2016. Pengaruh Kebijakan Dividen Terhadap Nilai Perusahaan Yang Tercatat Pada Indeks Lq-45 Bursa Efek Indonesia. Jurnal Wira 
Ekonomi Mikroskil Volume 6, Nomor 01.

Sugiyono. 2017. Metode Penelitian Kuantitatif, Kualitatif, dan R\&D. Bandung: Alfabeta.

Sulistiono. 2016. Pengaruh Struktur Modal, Kebijakan Dividen dan Investment Opportunity Set terhadap Nilai Perusahaan (Studi pada Perusahaanperusahaan Manufaktur di PT. Bursa Efek Indonesia) . Jurusan Akuntansi, Politeknik Negeri Malang.

Syardiana, Rodoni dan Putri. 2015. Pengaruh Investment Opportunity Set, Struktur Modal, Pertumbuhan Perusahaan, Dan Return On Asset Terhadap Nilai Perusahaan. UIN Syarif Hidayatullah Jakarta. Vol. VIII No.1.

Syifa. 2015. Pengaruh Investment Opportunity Set (Ios), Kepemilikan Institusional, Komisaris Independen, Dan Return On Investment (Roi) Terhadap Nilai Perusahaan Pada Perusahaan Manufaktur Yang Terdaftar Di Bursa Efek Indonesia. Skripsi. Fakultas Ekonomi Universitas Negeri Yogyakarta

Tarjo. 2008.

PengaruhKonsentrasiKepemili kanInstitusionadan Leverage Terhadap Manajemen Laba, NilaiPemegangsahamserta

Cost of Equity Capital. Simposium Nasioanal Akuntansi XI, Pontianak.
Tarigan, Josua dan Christiawan. 2007. Kepemilikan Manajerial : Kebijakan Hutang, Kinerja dan Nilai Perusahaan. Jurnal Akuntansi dan Keuangan, Vol. 9 No.1.

Pangalung. Pengaruh Kombinasi Keunggulan dan Keterbatasan Perusahaan terhadap Set Kesempatan Investasi (IOS), Jurnal Riset Akuntansi Indonesia. Vol. 6 no. 3, September 2003.

Permanasari. 2010. Pengaruh Kepemilikan Manajemen, Kepemilikan Institusional, Dan Corporate Social Responsibility Terhadap Nilai Perusahaan. Skripsi. Fakultas Ekonomi Universitas Diponegoro.

Putra. 2019. Pengaruh Kebijakan Dividen, Solvabilitas, Profitabilitas Dan Investment Opportunity Set Terhadap Nilai Perusahaan (Studi Pada Perusahaan Perbankan Yang Terdaftar Di Bei Tahun 20132017). Skripsi. Fakultas Ekonomi Universitas Islam Indonesia Yogyakarta. 